\title{
. \\ Science and environmental crisis amid fires and pandemia
}

\author{
Sandro Dutra e Silva \\ Pedro Roberto Jacobi \\ Zenaida Lauda-Rodriguez \\ Beatriz Milz
}

D I Deputy Editor of the Journal Ambiente $\mathbb{E}$ Sociedade. Full Professor in Centro Universitário de Anápolis - UniEVANGELICA. Professor in Universidade Estadual de Goiás.

(D) ${ }^{\text {II }}$ Chief Editor of the Journal Ambiente 85 Sociedade. Full Professor in the Faculty of Education, University of São Paulo. Professor of the Graduate Program in Environmental Science, University of São Paulo.

(D) III Member of the Editorial Executive Secretariat of Ambiente ES Sociedade Journal. Doctorate Student in the Graduate Program in Environmental Science, University of São Paulo. São Paulo/ SP - Brasil

(D) ${ }^{I V}$ Member of the Editorial Executive Secretariat of Ambiente EO Sociedade Journal. Doctorate Student in the Graduate Program in Environmental Science, University of São Paulo. São Paulo/ SP - Brasil
São Paulo. Vol. 24, 2021

Editorial

DOI: http://dx.doi.org/10.1590/1809-4422asoceditorialvu2021L1ED 
In our first editorial of 2020 (JACOBI et. al, 2020) we sought to reflect on the devastating fires that have hit Australia since 2019. At that time, our reflection on environmental variables was based on the ecological role and its relationship with the natural history of ecosystems, such as the Brazilian Cerrados, for example. However, the processes of climate change and the significant increase in global average temperature were very evident. These data were based on metrics pointed out by the world agencies of study and climate control, which in turn pointed to a less optimistic future climate scenario, with the forecast of the unprecedented increase of mega-fires on the planet.

In our first editorial of 2021, we were unable to announce more optimistic scenarios. This is because 2020 has proved to be even more tragic in every way. Environmental issues related to major climatic phenomena presented even more alarming indices. The great fires continued their tragic devastating path, destroying forest formations in Brazil, the United States, Australia, the Siberian Arctic, and other parts of the globe. And, unfortunately, Brazil continued to show high rates of fires in the Amazon and the Cerrado. However, in 2020 the Pantanal was the ecosystem most affected by the major fires, having $1 / 3$ of its territory consumed by fire. In addition to the devastation of the landscapes of this important Brazilian biome, the loss of biodiversity was unprecedented. The shocking images of burning animals and the desperate struggle of firefighters and volunteers to contain the spread of fire distincted the past year in a disturbing way.

According to data from the National Aeronautics and Space Administration (NASA), the United States Space Agency, and the European Union's Copernicus System, the major global fires of 2020 were the most devastating, considering the 18 years of research and generation of global data on forest fires. According to environmental historian Stephen Pyne, contemporary society is experiencing the Pyrocene era, a historical period in which mega-fires are more frequent, more dangerous, and more disturbing. According to Pyne, the Pyrocene would be equivalent, in environmental terms, to the global effects of the great glaciation (PYNE, 2020). And the effects of the major fires in Australia, California, the Arctic, tropical Africa, Indonesia, and Brazil will continue to affect the entire global climate, persistently for a long time to come.

It is worth noting that the year 2020 was the hottest ever recorded in the world, along with 2016, ending a decade of record temperatures that highlights the urgency of action against global warming, as presented by the Copernicus System, at the beginning of January 2021. The average global temperature increase was $1.25^{\circ} \mathrm{C}$ in relation to the pre-industrial era, with the years 2014 to 2020 being the hottest ever recorded. Scientists have called for governments and companies to drastically reduce their emissions so that there is a chance of meeting the goals of the 2015 Paris Accord and avoiding a catastrophic climate crisis.

In 2020 the United Nations warned the world community about the failure to meet the biodiversity protection targets set for this decade. And in this same context, a report published by the Intergovernmental Platform on Biodiversity and Ecosystem Services 
(IPBES) showed significant evidence for the extinction of species from 2020 onwards ${ }^{1}$. However, this same institution indicated in its report another serious global problem, equally threatening, that hit the world society in 2020, which was the COVID-19 pandemic. From what it called the Platform Workshop, IPBES sought to correlate biodiversity variables and pandemics, pointing out these issues as part of the central agenda of that tragic year. And so, between fires and pandemics, the year 2020 proved out to be strange, unfinished, complex and full of questions about the socio-environmental dilemmas for our near future.

In an article published at Nature on December 8, 2020, whose central theme dealt with the major fires that hit the Pantanal, the authors sought to conjecture the environmental tragedy to the critical numbers of deaths and infections by COVID-19 in Brazil (LIBONATI, 2020). As well as social issues, the Pantanal exposed the threats resulting from the lack of management and legal inefficiency, further intensifying the susceptible socio-environmental threats of this natural heritage.

But if the scenario seemed to have no room for further aggravation, 2020 proved that there is always a place for persistent stupidity. Combined with the Brazilian government's absurd speeches about the pandemic's denial, the Environment Minister Ricardo Salles suggested the approval of several environmental deregulations, taking advantage of the focus on COVID-19. As pointed out by the article published by Nature, the Brazilian government still tried to provide weak and unfounded justifications, ignoring the real causes of the fires: as a combination of inadequate fire management, climatic extremes, human behavior and weak environmental regulations (LIBONATI, 2020). And, to make matters worse, the Ministry of the Environment reduced funding for fire prevention, and when questioned by the spread of fire in Brazilian territory, he casted doubts on the reliability of geospatial research and data. The author's proposal is that researchers and the government need to strengthen the dialogue and develop comprehensive strategies for preventing and managing forest fires in Brazil, something that seems not to be feasible in times of denialists, especially in the most influential instances of environmental management in Brazil.

It can be said that the environmental and the pandemic crisis are strongly interconnected, since human pressure on the environment, with actions such as deforestation, the expansion of agriculture and livestock, the pressures of mining exploration, as well as various processes of environmental degradation, and the exploitation of species of wild fauna, have facilitated the transmission of diseases between animals and humans. However, although the resolution of the acute crisis resulting from Covid-19 may come through vaccination, new pandemics will come if one of its main causes, the environmental crisis resulting from the logic of production, is not resolved. It is worth emphasizing the importance of the dialogue between the environmental and social debate on health, especially regarding the fundamental role of the State in reducing risks for the most vulnerable population.

1- Intergovernmental Platform on Biodiversity and Ecosystem Services. IPBES Workshop on Biodiversity and Pandemics, Platform workshops, 27-31 July 2020. 
We conclude noting that the crises reveal societies uncertainties and risks - their best and worst characteristics. However, at the same time, crises also open up the possibility of reflecting on their contradictions and their ability to propose responses to uncertainties. Times of crisis are also times to build alternatives, in the direction of confronting wider systemic phenomena, strengthening the importance of science and decisions based on their assumptions, as well as risk governance institutions, in order to reduce vulnerabilities and ensure the protection of society and natural resources.

After this reflection, we invite everyone to enjoy the readings during the year of 2021, not without first thanking the entire editorial team of Revista Ambiente \& Sociedade, which, with academic rigour and quality, makes it possible to continue publishing articles within an interdisciplinary approach and discussion.

We opened this new annual volume with two articles corresponding to the special Dossier: Territories of Energy. The article: Science, Technology and Society: integrating the social sciences in the debate on energy, by the author Simone Abram, presents the main issues that the current social sciences aim at in the study of energy. Through a sociological and anthropological approach applied to the energy industries themselves, the social sciences can offer new theoretical perspectives, reveal the political relationships that accompany energy flows and offer new ways of thinking about the potential of current and future energy systems.

The author Bruno Fornillo, in the article: Energy transition in Uruguay: market dominance or public-social power?, characterizes the causes that led to the recent incorporation of renewable energy in Uruguay, with the objective of discussing how the energy transition in the country is thought. Uruguay has envisaged a renewal of its energy matrix, but is in a position to end up moving towards a just energy transition based on the country's public-social power.

In the Original Articles section, the paper: Socio-political-environmental perceptions of participants in the public hearings of the Brazilian Representative House on Environment, by the author Antonio Teixeira de Barros analyzes the perceptions of citizens who participated in the public hearings promoted by the Environment and Development Commission of the referred chamber during 2018. It concludes that there is a diversity of perceptions in relation to the Commission's agenda, as well as criticisms of the performance of parliamentarians and government representatives.

In order to reflect on the right of participation of Traditional Peoples and Communities in the environmental protection of their traditional territories in Extractive Reserves (RESEX), the authors Marcelo Lopes, Pedro Henrique Dias Marques and Priscilla Correa de Moura Estevão, analyze the legal aspects, positive and conceptual elements present in the national and international legal system that outline the scope of social participation. In the article: Community Environmental Monitoring: the management of commons in Cassurubá Extractive Reserve.

Ana Gabriela Godinho Lima and Rodrigo Mindlin Loeb, in the article: City, Gender and Climate Changes: Parelheiros as a case study in the capital of São Paulo, analyze the context of populations in situations of incomplete urbanization and recognize them as 
the most exposed to the risks of effects of climate change. For this reason, these populations must receive attention from initiatives that strengthen them socially and economically to face these effects. In this scenario, women and children are the most vulnerable groups.

In order to work on guidelines to support a methodological approach that explains the relationships between deforestation and urbanization, the article: The Interface between Deforestation and Urbanization in the Brazilian Amazon, by Julia Corrêa Côrtes and Roberto Donato da Silva Júnior, performs a review of the approaches of social theory of mobility and risk, reflecting on the conception of a critical theory consistent with the multidimensionality and transescalarity of the socio-landscape configurations of the urban fabric.

Maritza Marin-Herrera, Heidy Correa-Correa and Gustavo Blanco-Wells analyze the discourses and collective hermeneutics in relation to REDD+, and conclude that its implementation makes it possible to i) commercialize the nature and forms of traditional governance; ii) consolidate an eco-governmentality based on the fragmentation of nature; and iii) build representations about impoverished indigenous people, to justify intervention in their territories. In the article: Territorialization of the REDD + strategy in the Bribri indigenous people, Talamanca, Costa Rica.

In the article: Landscape planning and climate changes: a multidisciplinary approach in São Carlos (SP), the authors Renata Bovo Peres and Luciana Bongiovanni Martins Schenk discuss the experience of the Urban Parks Working Group in the city of São Carlos (SP), as an example of the interaction between science and planning practice. They conclude that adaptability depends on understanding the vulnerabilities of each context, valuing the public dimension, as well as scientific and political integration.

In order to analyze socioenvironmental vulnerability in the Sao Paulo Macrometropolis, the author Humberto Prates da Fonseca Alves associates two concepts from the literature on vulnerability and reveals that 1.8 million people live in areas with high socioenvironmental vulnerability, with emphasis on differences in coverage of sewage in homes in subnormal agglomerates. In the article: Socio-environmental vulnerability in the São Paulo Macro-metropolis' three main metropolitan regions: a socio-environmental indicators analysis.

The authors Natalia de Miranda Grilli, Mariana Martins de Andrade, Luciana Yokoyama Xavier, Cláudia Regina Santos, Fernanda Terra Stori, Cauê Dias Carrilho, Felipe Otavio Nunes, Melissa Vivacqua, Thiago Zagonel Serafini, Paulo Antonio de Almeida Sinisgalli, Cristiana Simão Seixas, Pedro Roberto Jacobi and Alexander Turra, in the article Step by step: a participatory action-research framework to improve social participation in coastal systems, highlight and discuss changes in the social participation of a coastal community in southeastern Brazil (Araçá Bay), resulting from a participatory action research that lasted three years.

In the article: The International Biodiversity Agenda at the Local Level: The Case of the Capybaras in Curitiba, Brazil, the authors Tatiana Maria Cecy Gadda, Jana Magaly Tesserolli de Souza, Gabriel Antônio Rezende de Paula, Tamara Simone van Kaick and João Henrique Diniz Brandão Gervásio demonstrate the socioecological relationships 
between the species studied and the urban environment, which suggest that the city only partially considers the Aichi Goals. Local authorities face major challenges in adopting the global biodiversity agenda.

We end this first delivery with the book Review: The King is naked!, written by Dr. Bjørn Lomborg, made by Carlos Germán Meza. In the reviewer's view, Lomborg's book criticizes the approach that some sectors of society have taken towards climate change and proposes policies to face the problem, and although recognizing the existence of anthropogenic climate change, his analysis and proposals to deal with the problem raise heated debates between academics and analysts.

We wish you all a good reading!

\section{References}

JACOBI, P. R. et al. O que indicam os incêndios na Austrália - Reflexões sobre seus alcances. Ambient. soc., São Paulo, v. 23, e0001, 2020. Available in: <http://www.scielo.br/scielo. php?script $=$ sci_arttext\&pid $=S 1414-753 X 2020000100201 \& \operatorname{lng}=$ en $\& n r m=$ iso $>$. Access on 05 Jan. 2021.

LIBONATI, R et al. Rescue Brazil's burning Pantanal wetlands. Nature, v. 588, 10 December, 2020, p. 217-219.

PYNE, S. The Australian fires are a harbinger of things to come. Don't ignore their warning. The Guardian, Tue 7 Jan 2020. 


\section{Sandro Dutra e Silva}

ఐsandrodutr@hotmail.com

ORCiD: https://orcid.org/0000-0002-0001-5726

\section{Pedro Roberto Jacobi}

$\square$ prjacobi@gmail.com

ORCiD: http://orcid.org/0000-0001-6143-3019

\section{Zenaida Luisa Lauda-Rodriguez}

$\square$ zeni.lauda.rodriguez@gmail.com

ORCiD: https://orcid.org/0000-0003-2432-0255

\section{Beatriz Milz}

$\square$ beatriz.milz@usp.br

ORCiD: https://orcid.org/0000-0002-3064-4486

How to cite: DUTRA E SILVA et al. Science and environmental crisis amid fires and pandemia. Ambiente \& Sociedade. São Paulo, v. 24, p. 1-7 , 2021. 